\title{
MYTHOLOGIZATION AND LEGITIMIZATION STALIN's TERror IN MODERN RUSSIAN INFORMATION SPACE
}

\section{MitologizacJA I LEGITYMiZACJA TERRORU STALINOWSKIEGO WE WSPÓŁCZESNEJ ROSYJSKIEJ PRZESTRZENI INFORMACYJNEJ}

\begin{abstract}
Through the means of implementation and spreading of Russian myths and stereotypes legitimization and justification of Russia's aggressive policy regarding to its own people and peoples of neighboring countries has been continuing.

Purpose. The purpose of the article is to analyze manifestations of use of social networks and feature films as means of mythologization and legitimization of Stalin's terror in modern information space based on results of social surveys.

Methods. Analyses and generalization of making up headlines events and results of sociological surveys have been performed. Deduction technique as a process of logical concluding based on the complex of analyzed facts as well as summarizing have been applied.

Conclusions. Public surveys have shown that in Russian society gradual depreciation of terror scale and moral damage are taking place. Mass character growth in positive opinion about Stalin and positive technique of Stalin's repressions are accompanied by lack (misunderstanding) of certain phenomena and events of Stalin's epoch. Myths and stereotypes in the case described have many social functions, most important of which are legitimization of history, justification of existing social system and mobilizing function. Growing popularity of Stalin is manifestation growth of not only conservative disposition, but also authoritative and repressive tendencies in Russian society.
\end{abstract}




\section{STRESZCZENIE}

Poprzez wdrażanie i rozpowszechnianie rosyjskich mitów i stereotypów trwa legitymizacja i uzasadnianie agresywnej polityki Rosji wobec własnego narodu i ludów sąsiednich krajów.

Celem artykułu jest analiza różnorodności wykorzystania sieci społecznościowych i filmów fabularnych jako sposobu mitologizacji i legitymizacji terroru Józefa Stalina we współczesnej przestrzeni informacyjnej na podstawie wyników badań socjologicznych.

Przeprowadzono analizę doniesień prasowych i wyników badań socjologicznych. Zastosowano technikę dedukcyjną dla wnioskowania na podstawie zestawu analizowanych faktów oraz metodę podsumowania.

Wyniki badań opinii publicznej pokazują, że stopniowo zaniża się przedstawianą społeczeństwu rosyjskiemu skalę panującego w kraju w czasach stalinowskich terroru i szkód moralnych. Wzrostowi życzliwości wobec Stalina i pozytywnemu odbiorowi represji stalinowskich towarzyszy brak dokładnej wiedzy i zrozumienia pewnych zjawisk, kwestii, wydarzeń z epoki Stalina. Mity i stereotypy w opisywanym przypadku pełnią wiele funkcji społecznych, z których najważniejszymi są legitymizacja historii, usprawiedliwienie istniejącego systemu społecznego oraz funkcja mobilizacyjna. Rosnąca popularność Stalina jest przejawem wzrostu nie tylko konserwatywnych nastrojów, ale także autorytarnych i represyjnych trendów w społeczeństwie.

KEYWORDS: mythologization, terror legitimization, information space, social network, propaganda film, Joseph Stalin, Russia.

SŁOWA KLUCzowe: mitologizacja, legitymizacja terroru, przestrzeń informacyjna, sieć społecznościowa, film propagandowy, Józef Stalin, Rosja.

\section{WPROWADZENIE}

Przez lata za pomocą rozpowszechniania mitów i stereotypów legitymizuje się i uzasadnia agresywną politykę carskiej Rosji, ZSRR i Federacji Rosyjskiej w stosunku do własnych obywateli i krajów sąsiednich. Przejawy takiej polityki informacyjnej można obserwować w publikacjach szerokiej gamy nowoczesnych mediów, sieci społecznościowych (Sokolova, 2018; Sokolova, 2019c) oraz w produkcji kinematograficznej. Można tu wymienić przepisywanie historii przez rosyjską historiografię w stosunku do praw dziedzictwa Rusi Kijowskiej (Sokolova, 2017), radzieckie mity o przyczynach głodu w latach 1932-1933 w Ukrainie (Sokolova, 2019b), mitologizowanie katastrofy 
w Czarnobylu w 1986 r. (Sokolova, 2019a) itp. Szczególną rolę w takich procesach odgrywają kategorie: wiedza, informacja i technologia, które Kateryna Novikova określa jako główne czynniki zmiany społecznej w globalnym kontekście (Novikova, 2016).

Mit jest wytworem określonego sposobu myślenia (obok myślenia zdroworozsądkowego). Cechuje go: większa zdolność do abstrakcji, przejawiająca się w rozróżnianiu tego, co może być doświadczone zmysłami, i tego, o czym można tylko myśleć (gr. mythos - legenda, przekonanie przyjmowane bez dowodu) (Sztumski, 2004, s. 321). Mit odbierany jest jak rzeczywistość, która nie potrzebuje dowodów oraz weryfikacji - wszystko przyjmowane jest na wiarę i bez wątpliwości.

Mitologia polityczna nie odzwierciedla rzeczywistości - jej celem jest zarządzanie świadomością zbiorową i zachowaniem ludzkich mas. W społeczeństwie totalitarnym nie tylko zastępuje ona rzeczywistość, ale również fizycznie ją wypacza. Mit apeluje nie do umysłu, ale do uczuć i emocji, do osobistych doświadczeń człowieka.

Można byłoby już nie powracać do historycznych mitów, które obala współczesna nauka. Lecz realia społeczeństwa informacyjnego są takie, że wciąż mamy do czynienia z rozpowszechnianiem starych mitów, zwłaszcza tych ideologicznie pożądanych dla agresywnej polityki Rosji. Bo dziś „...rozumieć informację należy nie tylko jako jej przekaz, ale również jako składnik organizujący system wartości” (Kovalskyi, 2017, s. 7; Sokolova, 2017).

Mity i stereotypy ,jako uproszczone, powierzchowne przekonania zbiorowe i jednostkowe są gruntem dla zakorzeniania się w ludzkiej świadomości wprawdzie realnych, ale niekompletnych i często fałszywych odzwierciedleń rzeczywistości. Korzystając z podstawowego i klasycznego rozróżnienia typów wiedzy na doxa i episteme dokonanego przez Platona, stereotypy reprezentują doxa. Doxa jako wiedza jest złudna, niepełna, niepewna, opozycyjna do obiektywności, czyli do episteme" - to sprawia, że stereotypowe myślenie wyprowadza społeczeństwo na manowce poznawcze (Korczyński, 2014, s. 14; Korczyński, 2017).

Szczególnie niebezpieczny jest wpływ zniekształconych informacji na dzieci i młodzież. Ponieważ zanurzenie w świat nieprawdziwy powoduje, 
że młody człowiek, „który nie jest jeszcze w pełni emocjonalnie ukształtowanym i którego system wartości dopiero się buduje, jest bardzo narażony" (Wróbel-Delegacz, 2019, s. 14) na niebezpieczeństwa związane z mitologizacją i stereotypizacją dokonywaną celowo za pośrednictwem m.in. propagandowych filmów fabularnych.

\section{„MĄDRE” MYŚLI TYRANÓW W SIECIACH SPOŁECZNOŚCIOWYCH}

$\mathrm{W}$ ostatnich latach $\mathrm{w}$ rosyjskiej przestrzeni informacyjnej ostro zarysowały się idee zakorzenione w ideologii radzieckiej. Jeszcze w 2010 r. Oleg Leszczak stwierdził, iż w reklamie rosyjskiej panuje moda „na transformacje starych plakatów radzieckich wykonanych $\mathrm{w}$ stylu socartu $\mathrm{z}$ dodaniem nowych treści reklamowych (typowy przykład - słynny żołnierz w budionówce pokazujący palcem na widza i pytający: Zaciągnąłeś się już na ochotnika?; we współczesnej wersji reklamowej pytanie brzmi: Sprawdziłeś już ceny?") (Leszczak, 2010, s. 334).

$\mathrm{Na}$ portalach społecznościowych co jakiś czas pojawiają się cytaty, przedstawiające wyrwane z kontekstu „mądre” myśli działaczy radzieckich. Za przykład niech posłuży zamieszczony na Facebooku rysunek ze słowami Stalina:

Trudno mi sobie wyobrazić, jaką „wolność osobistą" może mieć bezrobotny, który chodzi głodny, nie znajduje zastosowania dla swojej pracy. Prawdziwa wolność jest tylko tam, gdzie został wyeliminowany wyzysk, nie ma ucisku jednych przez drugich, nie ma bezrobocia i nędzy, gdzie człowiek nie boi się, że jutro straci pracę, mieszkanie, chleb. Tylko w takim społeczeństwie możliwa jest prawdziwa, a nie istniejąca na papierze, wolność osobista i każda inna. J. Stalin (zdj. 1, tłumaczenie Autoki artykułu).

Autor postu na Facebooku ma zwolenników komentujących cytat m.in. następująco: „Tak, będzie tak, towarzyszu J.W. Stalin!”. 
Zdjęcie 1.

Rysunek ze słowami Stalina zamieszczony na Facebooku

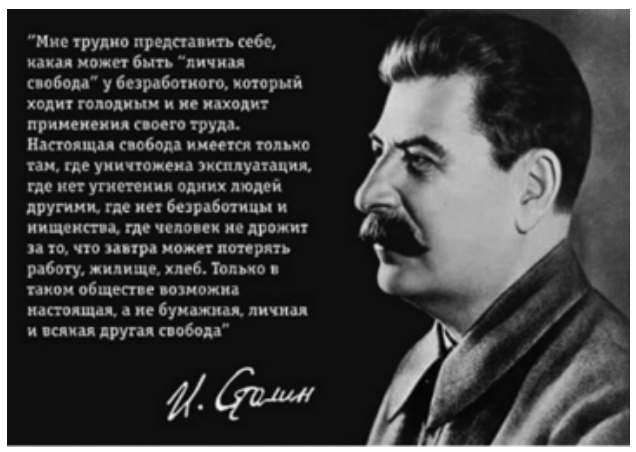

Źródło: (Kravchenko, 2018b).

Na portalu społecznościowym Facebook rozpowszechniane są również słowa Włodzimierza Lenina: „Robotnicy zarabiają tak mało, że zmuszeni są kupować tanie, niskiej jakości, podrabiane produkty, ale przecież główny konsument to robotnik. Robotników są miliony, kapitalistów setki. I oto wytwarzanie taniego, podrobionego produktu rośnie nie $\mathrm{z}$ dnia na dzień, ale z godziny na godzinę - wraz ze wzrostem niesłychanego luksusu garstki milionerów. W.I. Lenin” (zdj. 2, tłumaczenie Autorki artykułu). Autor postu komentuje cytat: „Wy niszczycie jego pomniki, a on ma przecież w 100 procentach rację..." W komentarzach do postu jeden z czytelników uzupełnia entuzjastyczną dyskusję nad przytoczonym cytatem propagandowym rysunkiem radzieckim, wykonanym przy użyciu nowoczesnych technik komputerowych; rysunek przedstawia wizję świetlanej przyszłości o nazwie „socjalizm”, przeciwstawionej upadkowi i śmierci, które nazwano „kapitalizm” (zdj. 3).

Zdjęcie 2.

Rysunek ze słowami Lenina zamieszczony na Facebooku 


\section{Zdjęcie 3.}

Rysunek zamieszczony na Facebooku, który przedstawia wizję świetlanej przyszłości o nazwie „socjalizm”, przeciwstawionej upadkowi i śmierci, które nazwano „kapitalizm”

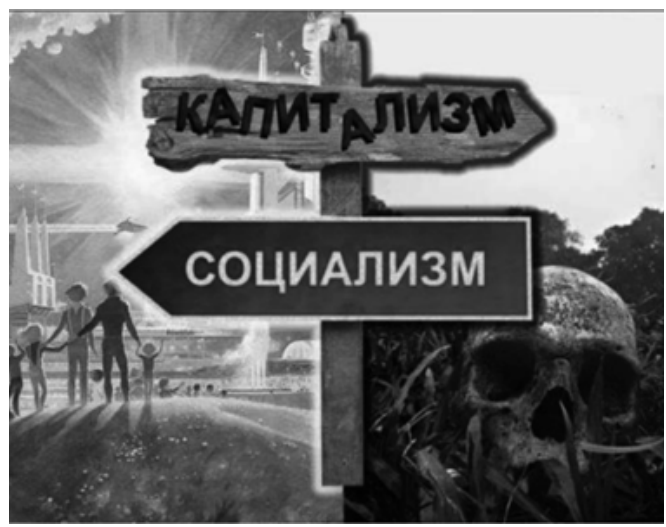

Źródło: (Yan’ko, 2018).

Rozpowszechnia się także grafiki zawierające pewien podtekst, np. zdjęcie współczesnych uzbrojonych żołnierzy z podpisem: „Droga do domu. Przysięgaliśmy ojczyźnie, której już nie ma. Żyjemy, jesteśmy w drodze” (zdj. 4).

Zdjęcie 4.

Rysunek zamieszczony na Facebooku z podpisem: „Droga do domu”

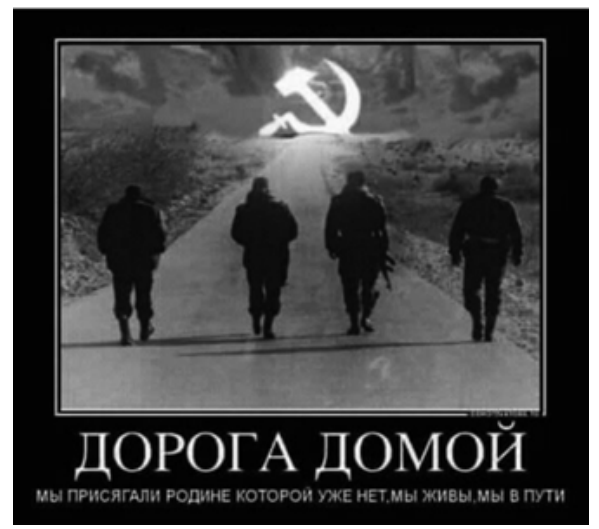

Źródło: (Kravchenko, 2018a). 
Te i wiele innych postów mają wspólną cechę: głoszą one tezy lub hasła, które w okresie ZSRR stanowiły wyróżnik ideologii radzieckiej. Tego rodzaju cytaty i hasła zawierają zasady sprawiedliwości społecznej i na niej koncentruje się uwaga czytelników. Ciemne strony działań autorów cytatów oraz zjawiska, które doprowadziły do śmierci milionów ludzi, we wspominanych postach są przemilczane lub pomijane.

\section{Polityczne uzAsadnianie TERRORU W FILMACH FABULARNYCH}

Współczesne rosyjskie filmy propagandowe gloryfikują radzieckie państwowe organy bezpieczeństwa i usprawiedliwiają terror radziecki. Jednym z przykładów jest legitymizacja deportacji Tatarów krymskich, przeprowadzonej w dniach 18-21 maja 1944 r., kiedy to na rozkaz Stalina z Krymu (historycznej ojczyzny Tatarów) wysiedlono 191044 Tatarów krymskich w odległe rejony Związku Radzieckiego (od Przyurala po republiki Azji Środkowej). Cynizm współczesnej propagandy wyraża się m.in. tym, że reżyser filmu pt. Most na Krym. Zbudowany $z$ miłością! (Krymskiy most..., 2018, 00:00:24) słowa usprawiedliwiające wspomniane wydarzenia wkłada $\mathrm{w}$ usta jednego $\mathrm{z}$ bohaterów filmu - syna deportowanych Tatarów krymskich. O swej deportowanej rodzinie Damir Nadyrowicz mówi: „Wysłali - to znaczy, że tak było trzeba”; bohater wychwala Stalina i stale oglądając telewizję, z pełną aprobatą przyjmuje słowa prezentera telewizyjnego: „Demokracja na wzór zachodni nie sprawdza się jednakowo we wszystkich krajach...” (Dolin, 2018). Należy tu m.in. podkreślić, że głównym źródłem finansowania produkcji wspomnianego filmu były środki państwowe Federacji Rosyjskiej (Fokhti in., 2018).

W filmie pt. Zabić Stalina jeden z głównych bohaterów (Jewhen Nowickij) wypowiada się o swej rodzinie, którą rozstrzelano pod zarzutem szpiegostwa: „Pewnie moi rodzice jednak byli winni” (Ubit' Stalina..., 2013, odcinek 3, 00:49:38). Stalin został w filmie przedstawiony pozytywnie - jako życzliwy wobec podwładnych przełożony i troskliwy przywódca państwa. Film wzmacnia tradycyjny rosyjski stereotyp „dobrego cara i złych bojarów”. „Złego bojara” w tym filmie uosabia Ławrentij Beria - komisarz generalny spraw wewnętrznych ZSRR od 30 stycznia 1941 r. do 6 lipca 1945 r. 


\section{STALIN W WYNIKACH BADAŃ SOCJOLOGICZNYCH}

Tendencje nostalgiczne i polityka apologii terroru radzieckiego w produkcjach filmowych i rosyjskich środkach masowego przekazu prowadzą w istocie do próby przywrócenia kultu Stalina. Wyniki badań socjologicznych Levada-Center pokazują, że w stosunku Rosjan do Stalina można wyróżnić trzy etapy: lata 2001-2006, kiedy to występowała dominacja postrzegania negatywnego, lata 2008-2012, cechujące się przewagą stosunku obojętnego i lata 2014-2018 z dominacją ocen pozytywnych (Pipiya, 2018; wyk. 1).

Wykres 1.

Stosunek Rosjan do Stalina

ЛЕВАДА-ЦЕНТР

АНАЛИТИЧЕСКИЙ ЦЕНТР ЮРИЯ ЛЕВАДЫ

«Как Вы в целом относитесь к И. Сталину?»

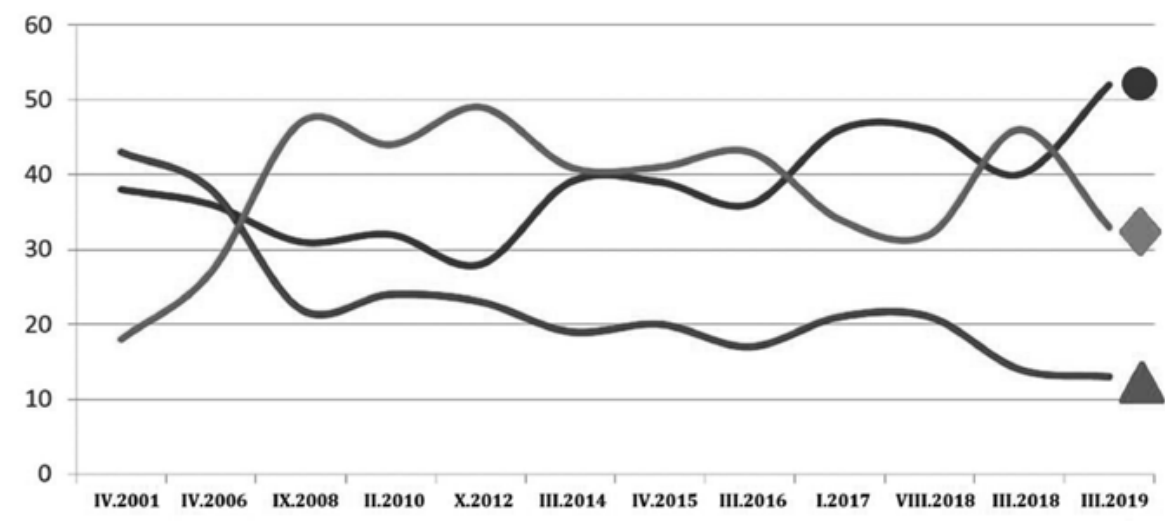

Znaki umowne:

• „podziw” + „szacunek” + „sympatia”; $\boldsymbol{\Delta}$ „wrogość” + „strach” + „odraza”; „obojętność” + „nie wiem”.

Źródło: (Funktsii mifa: o chem govorit..., 2019, 00:19:50).

Od roku 2015 liczba neutralnie lub negatywnie nastawionych wobec Stalina Rosjan spada. Według sondażu przeprowadzonego w marcu $2019 \mathrm{r}$. $70 \%$ Rosjan uważa jego rolę za pozytywną, co jest rekordem w całym okresie przeprowadzenia sondaży. Tylko 19\% respondentów jego rolę w życiu kraju ocenia negatywnie (wyk. 2). 
Wykres 2.

Ocena przez Rosjan roli Stalina w radzieckiej historii

ЛЕВАДА-ЦЕНТР

АНАЛИТИЧЕСКИЙ ЦЕНТР ЮРИЯ ЛЕВАДЫ

«Как бы Вы оценили роль Сталина в советской истории, истории нашей страны?»

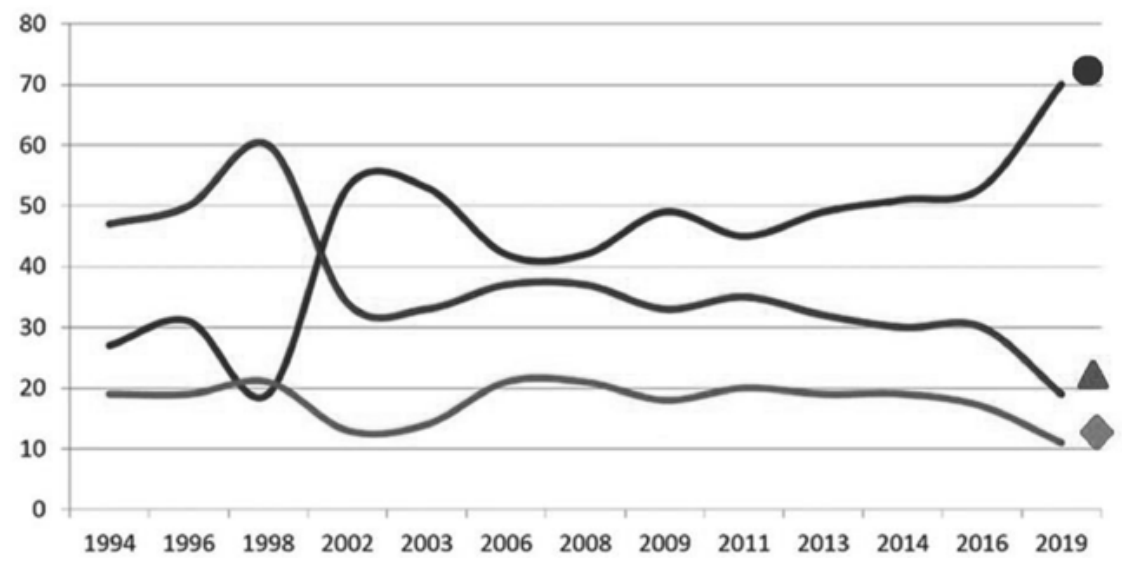

Znaki umowne:

- „ogólnie pozytywnie”; \ „ogólnie negatywnie”; "trudno odpowiedzieć”.

Źródło: (Funktsii mifa: o chem govorit..., 2019, 00:09:25).

Socjolog Denis Wołkow stwierdza, że tłem wzrostu pozytywnego stosunku do Stalina stała się aneksja Krymu - społeczeństwo odebrało to wydarzenie jako symbol odrodzenia potęgi kraju, która powstała - w wyobrażeniu wielu Rosjan - właśnie w czasach, gdy władzę sprawował Stalin, a upadła wraz z rozpadem ZSRR. Badacz uważa, iż takim nastrojom w społeczeństwie rosyjskim sprzyja pozycja władzy: w czasie prezydentury Dmitrija Miedwiediewa publicznie poddawano pod dyskusję i intensywnie opracowywano program destalinizacji, zaś powrót Władimira Putina na urząd prezydenta przyniósł zmianę pozycji władzy w stosunku do Stalina (Volkov, 2017). Zdaniem Borysa Parachońskiego (Parakhonskyi, 2017, s. 58) „Moskwa... znajduje w przeszłości wzory do naśladowania - dzisiejsze społeczeństwo rosyjskie faktycznie ożywia wartości i stereotypy egzystencjalne minionych czasów. Tyle że zamiast starych haseł »walki ze światowym kapitałem « wprowadza się retorykę "walki cywilizacji«". 
Socjologowie zauważają w rosyjskim społeczeństwie ogromne zapotrzebowanie na mit o Stalinie, na idealizację sowieckiej przeszłości. Socjolog Lew Gudkow łączy to z przyczynami takimi jak:

- potrzeba wyrażenia niezadowolenia z obecnego stanu rzeczy,

- wzrost ciemnego rosyjskiego nacjonalizmu, imperialnych nastrojów,

- próba przezwyciężenia traumy niepowodzenia budowania demokracji,

- próba przezwyciężenia traumy rozpadu ZSRR,

- bardzo głębokie frustracje (Nelyubin, 2020).

Według L. Gudkowa mit Stalina jest warunkiem przyjęcia obecnego porządku - jest to uznanie bezradności i zależności osoby od władzy oraz brak możliwości uświadomienia sobie i zaakceptowania tego (Funktsii mifa: o chem govorit..., 2019, 01:57:24). Alexey Levinson podkreśla, że wszystkie pytania dotyczące Stalina, które są zadawane, i wszystkie udzielane na nie odpowiedzi padają w kraju, gdzie jest postać znacznie ważniejsza niż Stalin to Putin. Toczy się bardzo trudna gra: słuchając o Stalinie, zdecydowanie powinniśmy usłyszeć opowieść na temat Putina (Funktsii mifa: o chem govorit..., 2019, 01:30:00). Stanowisko to potwierdzają wyniki badań opinii publicznej, zgodnie z którymi pozytywne myślenie o Stalinie zbiega się z lojalnością wobec obecnego rządu (wyk. 3).

Gudkow podkreśla, że z mitem o Stalinie związane są niezwykle ważne zjawiska - rosnący wpływ i autorytet współczesnej policji politycznej, Federalnej Służby Bezpieczeństwa Federacji Rosyjskiej, armii i innych służb specjalnych. Dziś to oni w Rosji są na szczycie listy najbardziej wpływowych i wspieranych przez państwo instytucji. Dlatego nie chodzi tu o samego Stalina. Stalin jest tylko wskaźnikiem bardzo ważnych procesów, które można prześledzić zarówno w odniesieniu do policji politycznej, jak i do całkowitej kontroli, potrzeby wzmocnienia walki z wewnętrznymi wrogami itd. Jest to wzrost świadomości społeczeństwa rosyjskiego, że wokół są wrogowie. Nie jest jasne, kim są owi wrogowie. Ważne jest, aby wróg był postulowany i tym samym uzasadniał cały system represji władzy. Badania socjologiczne pokazują bardzo ważną rzecz - przeniesienie własnej odpowiedzialności i agresji na symboliczną postać lidera i nauczyciela. Funkcją dzisiejszego Stalina jest zachowanie systemu przemocy, samoizolacja, przeciwstawienie się Zachodowi i możliwość samostano- 
wienia za pośrednictwem siły. Jest to bardzo ważna funkcja kompensacyjna za poczucie zależności obywateli Rosji od własnej władzy i niesprawiedliwość w życiu codziennym. W tym sensie „mały człowiek” (czyli zwykły obywatel) odwołuje się do mitycznej „idealnej” przeszłości, kiedy „był porządek”, kiedy „za Stalina” nie było korupcji itp. Jest to wskaźnik zależności od władzy (Funktsii mifa: o chem govorit..., 2019, 01:59:47).

Wykres 3.

Wyniki odpowiedzi Rosjan na pytanie o dziesięć najwybitniejszych osób wszechczasów

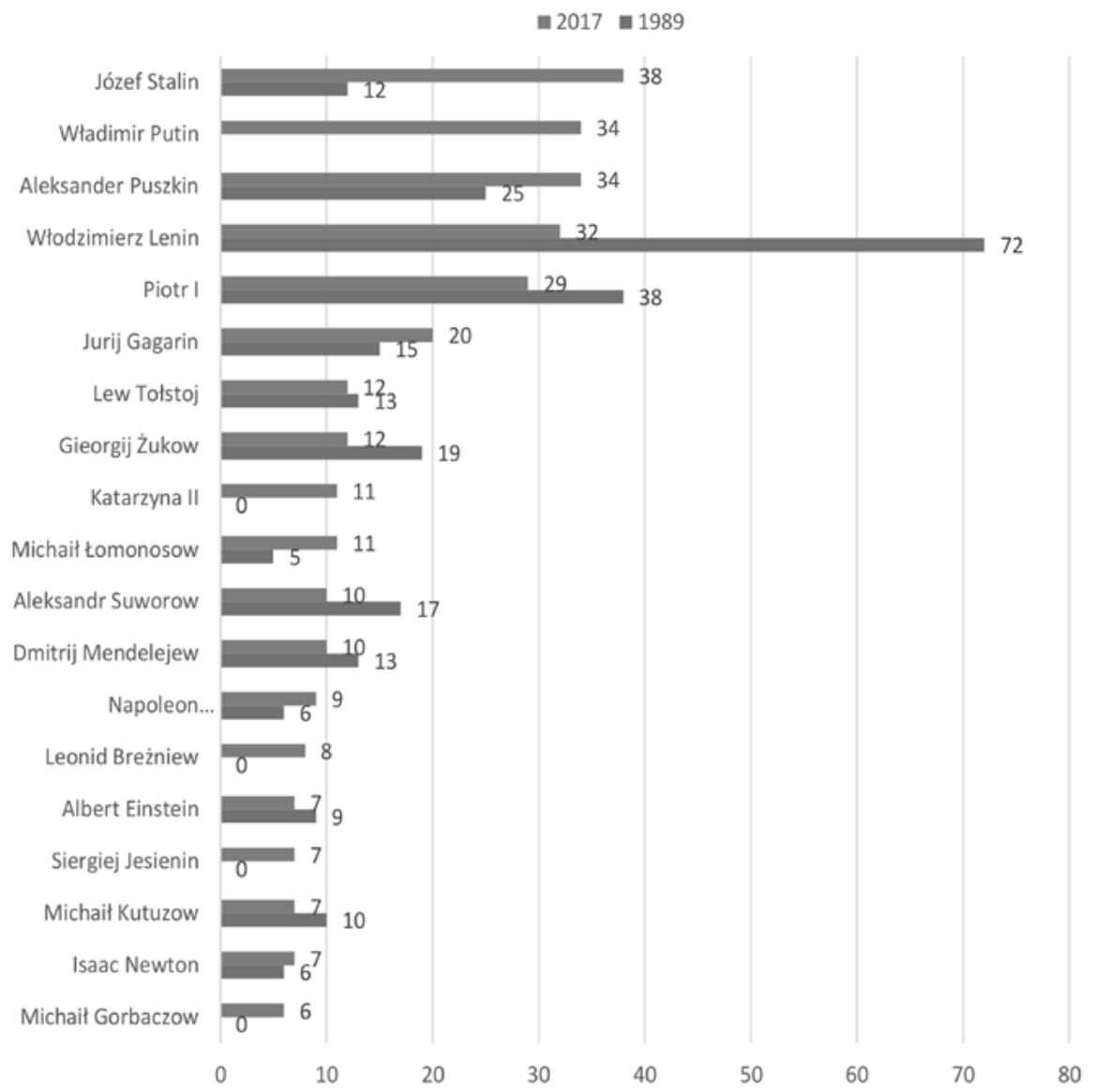

Źródło: opracowanie własne na podstawie danych Levada-Center (Raspredeleniye otvetov..., 2020). 


\section{Podsumowanie}

Wyniki badań opinii publicznej pokazują, że stopniowo zaniża się przedstawianą społeczeństwu rosyjskiemu skalę panującego w kraju w czasach stalinowskich terroru i szkód moralnych. W Rosji państwo dokłada wszelkich starań, aby pamięć o epoce Stalina stanowiła podstawę jasnej i pozytywnej narracji o kraju. Wzrostowi życzliwości wobec Stalina i pozytywnemu odbiorowi represji stalinowskich towarzyszy fakt, że ludzie znają historię tej epoki równie słabo, jak historię wszystkich innych epok. A zatem ważną przyczyną powstawania analizowanych mitów jest m.in. brak dokładnej wiedzy i zrozumienia pewnych zjawisk, kwestii, wydarzeń. Nie znając konkretnych faktów, jednostka samodzielnie tworzy we własnej wyobraźni pewne związki przyczynowo-skutkowe, łączy cechy niecharakterystyczne.

U podstaw technologii mitologizacji leży teza o tym, że kłamstwo powtórzone tysiąc razy staje się prawdą. Żeby osiągnąć zaplanowany efekt, pewna informacja w sposób ukierunkowany i systematyczny zostaje skierowana do najpopularniejszych mediów. Media państwowe, portale społecznościowe, filmy fabularne w tej sytuacji zwiększają efekt, a czasem są podstawą tworzenia takich mitów.

Mity i stereotypy pełnią wiele funkcji społecznych, z których najważniejszą w opisywanym przypadku jest legitymizacja historii. Usprawiedliwiają system społeczny i często takie uzasadnienie odbywa się kosztem interesów grupowych i jednostkowych. Pełnią też funkcję mobilizacyjną - wraz z rozpowszechnieniem przekonania, że wszędzie są wrogowie, kształtuje się w wyobraźni osób korzystających z rosyjskiej przestrzeni informacyjnej pozytywny odbiór możliwości samostanowienia przez zastosowanie siły np. w Gruzji, w Ukrainie, w Syrii itp.

Na podstawie wyników badań sondażowych badacze społeczeństwa rosyjskiego stwierdzają, iż w Rosji doszło do odrodzenia dualizmu konceptów „patriotyzm - duma”, dominującego w świadomości społecznej obywateli byłego Związku Radzieckiego (Gulyakhin i in., 2018, s. 187). Jak twierdzi Gudkow, rosnąca popularność Stalina jest przejawem wzrostu nie tylko nastrojów konserwatywnych, ale także autorytarnych i represyjnych trendów w społeczeństwie (Nelyubin, 2020). Według Alexeya Levinsona najważniejszy jest brak kary dla złodzieja, którego okrucieństwa nie są dla nikogo tajemnicą. 
Dokonując predykcji, można powiedzieć, że oznacza to, że w zasadzie wszystkie działania postaci historycznej w Rosji (np. Putina) mogą liczyć na bezkarność (jak było np. ze Stalinem). Jest to sygnał zarówno dla autorytarnego władcy, jak i obywateli (Funktsii mifa: o chem govorit..., 2019, 01:30:00) i może mieć kontrowersyjne konsekwencje.

Dalsze badania nad technologiami i kierunkami mitologizacji rosyjskiej przestrzeni informacyjnej są ważnym elementem międzynarodowych i krajowych środków polityki, mającej na względzie bezpieczeństwo sąsiednich krajów Federacji Rosyjskiej.

\section{Bibliografia}

Dolin, A. (2018). Spyativshaya mashina vremeni: o patrioticheskoy komedii „Krymskiy most. Sdelano s lyubov'yu!' po stsenariyu Margarity Simon'yan [Crazy Time Machine: about patriotic comedy "Crimean Bridge. Made with Love!" based on scenario of Margarita Symonian]. Meduza. Opublikowano 1.11.2018, https://meduza.io/feature/2018/11/01/spyativshaya-mashina-vremeni (dostęp: 20.03.2020).

Fokht, E., Rustamova F., Milyukova Ya., Kozlov P. (2018). Na komediyu „Krymskiy most" dali den'gi bez konkursa. Zritelyam ona ne nravitsya ["The Crimean Bridge” comedy was given money without competition. Viewers don't like it]. BBC. Opublikowano 7.11.2018, https://www.bbc.com/russian/news-46129808 (dostęp: 20.03.2020).

Funktsii mifa: o chem govorit nam dinamika massovogo otnosheniya $k$ Stalinu. Prezentatsiya rezul'tatov oprosov obshchestvennogo mneniya Levada-tsentra «Dinamika otnosheniya $k$ Stalinu» i ekspertnaya diskussiya [Myth's functions: what dynamics of mass attitude to Stalin tells us about. Presenation of public opinion survey results performed by Levada-Center "Dynamics of Attitude to Stalin" and expert discussion]. Levada-Center: Yuri Levada Analytical Center. Opublikowano 10.06.2019, https://www.levada.ru/2019/06/10/funktsii-mifa-o-chem-govorit-nam-dinamikamassovogo-otnosheniya-k-stalinu/ (dostęp: 20.03.2020).

Gulyakhin, V.N. i in. (2018). Stereotipy politicheskogo myshleniya molodezhi v kontekste realizatsii strategii natsional'noy bezopasnosti RF: opyt regional'nogo issledovaniya [Stereotypes of political thinking in the context of realization of national Russian Federation security strategy: experience of regional research]. „Science Journal of Volgograd State University: History. Area Studies. International Relations", No. 2, Vol. 23, s. 186-194. DOI.org/10.15688/jvolsu4.2018.2.16. 
Korczyński, T.M. (2014). Stereotyp narodowy a socjologia wiedzy. Przyczynek do teoretyczno-metodologicznego modelu socjologicznego badania zjawiska stereotypu narodowego w ujęciu fenomenologicznej socjologii wiedzy, Warszawa: ISKK. ISBN 8385945253.

Korczyński, T.M. (2017). Wizerunek Rosjanina w Polsce. Socjologiczna analiza zjawiska stereotypu narodowego w paradygmacie socjologii wiedzy, „Journal of Modern Science", nr 32/1, s. 29-44. ISSN 1734-2031.

Kovalskyi, H. (2017). Aksiolohichna ploshchyna zovnishnikh chynnykiv informatsiynoho protystoyannya $v$ Ukrayini [Axiological Dimension of the External Factors of Informational Confrontation in Ukraine]. „Intercultural Communication”, No. $1 / 2$, s. 5-14.

Kravchenko, S. (2018a). Facebook. Opublikowano 19.12.2018, https://www.facebook.com/photo.php?fbid=1775646682562024\&set=ecnf.100003501277881\&type=3\&theater (dostęp: 15.03.2019).

Kravchenko, S. (2018b). Facebook. Opublikowano 16.12.2018, https://www.facebook.com/permalink.php?story_fbid $=1770569493069743 \&$ id $=100003501277881$ (dostęp: 15.03.2019).

Krymskiy most. Sdelano slyubov'yu! [The Crimean Bridge: Made with Love!]. (2018). Film: comedy, melodrama. Film director by Tigran Keosayan. Russia. Russian: Central Partnership. YouTube. Opublikowano 15.04.2020, https://www.youtube. com/watch?v=5B9Tn3DEWzY (dostęp: 20.04.2020).

Leszczak, O. (2010). Stereotypy w komercyjnym i politycznym dyskursie reklamowym. W: A. Kasińska-Metryka i M. Gołoś (red.), Mity i stereotypy w polityce: Przeszłość i teraźniejszość, Toruń: Wydawnictwo Adam Marszałek, s. 314-337. ISBN 9788376115658.

Nelyubin, N. (2020). „Tyaga k Stalinu - moral'naya tupost' obshchestva”. Direktor Levada-Center o nastroyeniyakh rossiyan [Attraction to Stalin is moral stupidity of the society. Director of "Levada-Center" about Russians' disposition]. FONTANKA.RU, https://www.fontanka.ru/2020/01/08/020/ (dostęp: 20.04.2020).

Novikova, K. (2016). Informacja, wiedza, technologia w wybranych koncepcjach zmiany społecznej, „Journal of Modern Science”, nr 29/2, s. 71-92. ISSN 1734-2031.

Parakhonskyi, B.O. (2017). Hibrydna real'nist' i svitovyy poryadok [Hybrid reality and world order]. W: V. Horbulin (red.), Svitova hibrydna viyna: ukrayins'kyy front [The World Hybrid War: Ukrainian Forefront], Kharkiv, Folio, s. 55-78. ISBN 9789660377608. Opublikowano 26.01.2017, http://www.niss.gov.ua/articles/2431/ (dostęp: 20.03.2020). 
Pipiya, K. (2018). Stalin v obshchestvennom mnenii [Stalin in social opinion]. Levada-Center: Yuri Levada Analytical Center. Opublikowano 10.04.2018, https://www. levada.ru/2018/04/10/17896/ (dostęp: 20.05.2020).

Raspredeleniye otvetov na vopros: "Nazovite, pozhaluysta, desyat' samykh vydayushchikhsya lyudey vsekh vremen i narodov». Struktura i vosproizvodstvo pamyati o USSR $v$ rossiyskom obshchestvennom mnenii: Po rezultatam initsiativnykh reprezentativnykh obshcherossiyskikh oprosov naseleniya [Distribution of answers to the question: "Name ten most remarkable people of all times and nations, please". Structure and reproduction of memory about Soviet Union in Russian public opinion: According to the results of all-Russian intiative and representative population surveys]. Levada-Center: Yuri Levada Analytical Center. Opublikowano 24.03.2020, https://www.levada.ru/2020/03/24/struktura-i-vosproizvodstvo-pamyati-o-sovetskom-soyuze-v-rossijskom-obshhestvennom-mnenii/ (dostęp: 20.05.2020).

Sokolova, S. (2017). The Russian-language Wikipedia as a Measure of Society Political Mythologization, „Journal of Modern Science”, nr 33/2, s. 147-176. ISSN 17342031.

Sokolova, S. (2018). Violations of Comparative Method Application within Internet Discussions of Fiction, „Journal of Modern Science”, nr 38/3, s. 87-109. ISSN 1734-2031.

Sokolova, S. (2019a). Formowanie alternatywnej rzeczywistości w społeczeństwie totalitarnym: mitologizacja Czarnobylskiej katastrofy w 1986 r., „Journal of Modern Science", nr 41/2, s. 39-60. DOI:10.13166/jms/110493. ISSN 1734-2031.

Sokolova, S. (2019b). Technology of Soviet Myth Creation about Famine as a Result of Crop Failure in Ukraine of the 1932-1933s, „Journal of Modern Science”, nr 42/3, s. 37-56. DOI:10.13166/jms/113374. ISSN 1734-2031.

Sokolova, S. (2019c). Uzasadnianie i argumentowanie w komunikacji z osobami poddanymi mitom i stereotypom, „Journal of Modern Science”, nr 43/4, s. 119-132. DOI:10.13166/jms/117852. ISSN 1734-2031.

Sztumski, J. (2004). Mit. Encyklopedia pedagogiczna XXI wieku. Tom III (M-O), Warszawa: Wydawnictwo Akademickie „Żak”. ISBN 8389501244.

Ubit' Stalina [To Kill Stalin]. (2013). Film: detective, spy movie. Film director by Sergey Genzburg. Russia. Star Media. Episode 3. Opublikowano 5.04.2014, https:// www.youtube.com/watch?v=eBCjLX_nt4 (dostęp: 20.05.2020).

Volkov, D. (2017). Stalinskiy vopros [Stalin's issue]. Levada-Center: Yuri Levada Analytical Center. Opublikowano 3.07.2017, https://www.levada.ru/2017/07/03/stalinskij-vopros/ (dostęp: 20.03.2020). 
Wróbel-Delegacz, W. (2019). Edukacyjno-wychowawcza rola rodziny w kształtowaniu kultury i poczucia bezpieczeństwa w cyberprzestrzeni, „Journal of Modern Science”, nr 43/4, s. 9-30. DOI: 10.13166/jms/117980. ISSN 1734-2031.

Yan’ko, A. (2018). Facebook. Opublikowano 26.12.2018, https://www.facebook.com/ permalink.php?story_fbid=2394555773951262\&id=100001905892743 (dostęp: 15.03.2019). 